\title{
Climate change and the potential economic benefits of heat-tolerant bean varieties for farmers in Atlántida, Honduras ${ }^{1,2}$
}

\author{
Timothy G. Porch ${ }^{3}$, Richard Bernsten ${ }^{4}$, \\ Juan Carlos Rosas ${ }^{5}$, and Molly Jahn ${ }^{6}$
}

J. Agric. Univ. P.R. 91(3-4): 133-148 (2007)

\begin{abstract}
Rising ambient air temperatures, migration, and deforestation threaten the sustainability of hillside agriculture in Atlántida, Honduras. Currently, farmers avoid climatic constraints to common bean production by planting at different altitudes during different seasons. However, this practice may become less effective because of climatic change. The analysis of historical weather data from 14 weather stations indicates that Honduras is undergoing climatic warming and GIS analysis shows a significant proportion of bean production under high temperature stress conditions. Farmers in ten villages in Atlántida, five at a lower altitude and five at a higher altitude, were interviewed in regard to their knowledge and experience with climatic change and bean production. Differences in bean production and yield between the low altitude and high altitude villages were attributed mainly to climatic constraints, due to differences in elevation. Under base scenario assumptions, a cost/benefit analysis indicates that the development and in-
\end{abstract}

${ }^{1}$ Manuscript submitted to Editorial Board 10 Oetober 2006.

2This study was made possible through a National Science Foundation Graduate Fellowship to Tim Porch, Cornell CIIFAD funding, the Cornell Bradfield Award, and the Bean' Cowpea CRSP. The climate data were provided by the Dirección General de Aeronáutica Civil de Honduras, Toncontin Airport, Tegucigalpa, Honduras. We are grateful to Elena Mikhailova for establishing the collaboration with Toncontin Airport, to Noel Yap for writing the code in Perl, to Charles MeCulloch for statistical consulting, to Dan Wilks for advice on meteorological data analysis (all of Cornell University), and to Orlando Mejia for the GIS analysis (Michigan State University). The questionnaire was based on the design of Pedro Martel; David Mather assisted with the cost/benefit analysis (both of Michigan State University). In Honduras, Suyapa Serrano was of invaluable assistance with the farmer interviews. We thank Sally Humphries (IPCA) and Rafael Carias (CURLA) for institutional support and guidance. Most of all, we are grateful to the farmers of Atlántida for sharing their personal stories in spite of the tremendous constraints and poverty they face.

${ }^{3}$ Research Plant Geneticist, USDA/ARS, Tropical Agriculture Research Station, 2200 P.A. Campos Ave., Suite 201, Mayagüez, PR 00680.

${ }^{4}$ Professor, Department of Agricultural Economics, Michigan State University, 211 E. Agriculture Hall, East Lansing, Michigan.

${ }^{5}$ Professor, Escuela Agrícola Panamericana (Zamorano), P.O. Box 93, Tegucigalpa, Honduras.

${ }^{6}$ Dean, Professor, College of Agricultural and Life Sciences, 140 Agricultural Hall, 1450 Linden Dr., Madison, WI 53706. 
troduction of heat-tolerant bean varieties could produce significant returns and help to alleviate heat-related constraints on bean production.

Key words: climate change, cost benefit analysis, heat tolerance, Phaseolus vulgaris, plant breeding

\section{RESUMEN}

Cambios climáticos y beneficios económicos en la utilización de variedades de frijol tolerantes a temperaturas altas para agricultores en Atlántida, Honduras

El aumento en temperatura ambiental, la emigración y la deforestación amenazan la agricultura sustentable en la zona montañosa de Atlántida, Honduras. Para evitar limitaciones climáticas, agricultores de esta zona producen frijol mediante siembras a distintas elevaciones. Sin embargo, esta práctica puede ser poco efectiva debido a cambios climáticos. Estudios de datos climatológicos históricos obtenidos de 14 estaciones meteorológicas indican que la temperatura ambiental en Honduras va en aumento. Estudios de información geográfica demuestran que gran parte de la producción de frijol ocurre en áreas donde las temperaturas son elevadas. Se entrevistaron agricultores en villas localizadas en elevaciones altas y en elevaciones bajas para determinar sus experiencias con cambios climáticos y el efecto en la producción de frijol. Las diferencias en rendimiento fueron causadas por limitaciones climáticas atribuidas a la producción de frijol a diferentes elevaciones. Un análisis de costos/beneficios indica que el desarrollo y la introducción de variedades tolerantes a temperaturas altas pueden resultar en ganancias sustanciales para el agricultor mediante la disminución de problemas asociados a altas temperaturas en la producción de frijol.

Palabras clave: cambios climáticos, análisis de costos/beneficios, tolerancia a alta temperatura, Phaseolus vulgaris, fitomejoramiento

\section{INTRODUCTION}

During the past 40 years, common bean (Phaseolus vulgaris L.) has been introduced into the Honduran lowland tropics by migrants from Western and Central Honduras who have rapidly settled the hillsides of the North Coast. A staple grain for most of Central America, this coolseason, highland crop has fared well in the higher temperature and higher humidity climate of the hillsides of Atlántida, largely because of farmers' innovations that adapt bean production to the environment. Nevertheless, sensitivity of common bean to high temperatures has limited yields, forced farmers to plant at higher altitudes, and encouraged deforestation. In addition, global climate change could pose a mounting threat to bean production in this tropical zone.

Dramatic changes are occurring in the global climate, including rising day and night temperatures (Stott et al., 2000). In the last 100 years, global average minimum temperatures have risen $1.86^{\circ} \mathrm{C}$ and maximum temperatures $0.88^{\circ} \mathrm{C}$ (Easterling et al., 1997). Studies on global climatic change reveal that global minimum temperatures are rising more rapidly than global maximum temperatures (Alward et al., 1999; Easterling et al., 2000; Harvey, 1995). However, predictions of cli- 
mate change are limited by the dearth of climate data for large areas of the world. Considerably less is known about warming in tropical, than in temperate, agroecological zones. In addition, few studies on the impact of climate change have been completed for Central and South America (Rosenzweig and Hillel, 1998).

Coupled with the asymmetric global warming trend, the widespread sensitivity to high night temperatures in common bean (Konsens et al., 1991), as well as in crops like cowpea (Warrag and Hall, 1984) and tomato (Went, 1945), could result in significant production losses in certain regions and crops. Common bean reproductive development is particularly sensitive to high temperature stress, which results in increased floral abscission, damage to male reproductive development resulting in pollen sterility, and a reduction in pod set, seed set, and yield (Gross and Kigel, 1994; Porch and Jahn, 2001; Rainey and Griffiths, 2002). Tolerance to heat stress in bean is heritable (Román-Avilés and Beaver, 2001, 2003), and plant breeding efforts have increased tolerance to heat stress (Rosas et al., 1999; RománAvilés and Beaver, 2003), thus suggesting that future substantial gains in genetic heat tolerance are possible.

Honduras, one of Central America's poorest countries, traditionally has been referred to as a banana republic, because of the century-long control of fruit production by foreign national companies along this country's Northern Atlantic coast and valleys. Early migration to Atlántida's coastal plains at the turn of the 19th century was largely a response to the opening of labor markets associated with the establishment of international fruit companies such as the United Fruit Company and the Standard Fruit Company. As a result of fluctuations in the labor needs of cooperatives, ranches, and foreign companies, and the large-scale migration of farmers to the Atlantic Coast from western areas of the country beginning in the 1970s (Zavala, 1993), farmers were increasingly forced to resort to cultivation of the steep hillsides of Atlántida.

Since the 1960s, the hillsides of Atlántida have undergone a shift from harboring a few scattered family farms (Humphries, 1996) to being an important production area for small grains, milk, beef, timber, and cash crops. Although in-migration has increased agricultural production in Atlántida, it has also contributed to extensive deforestation and land degradation due to the continual extension of the agricultural frontier into marginal mountain areas (Sunderlin, 1998). These trends have transformed the steep hillsides of the North coast into a new common bean production area in Honduras. As a result, in the late 1990s, Atlántida accounted for approximately $5 \%$ of the national bean production (UPEG, 1998a). In contrast, about $90 \%$ of the country's beans are produced in Western and Central Honduras (UPEG, 1998b), where the 
higher elevation results in cooler conditions, moderate humidity, and lower rainfall.

The Atlantic littoral zone comprises $16 \%$ of the Honduran land area and is characterized by high temperature, humidity, and rainfall conditions that extend to 600 meters above sea level (masl) (Portillo, 1997). The climate of Atlántida is characteristic of the lowland tropics with abundant rainfall, reaching 2500 to $3000 \mathrm{~mm} / \mathrm{yr}$ on average (van Wambeke, 1992). Rainfall is bimodal, increases with elevation (Zuniga, 1990) and occurs mostly between May and January. The average annual temperature of Atlántida is $26^{\circ} \mathrm{C}$ and ambient temperature decreases with increasing elevation. The soils of Atlántida's hillsides are Ultic Hapludalfs, Typic Dystropepts, and Typic Hapludults, Tropohumults and Tropohudults (Triomphe, 1996). They are slightly acidic ( $\mathrm{pH}$ 6), have good depth, and are formed from igneous metamorphic rock (Simmons, 1969). The coastal plains are Tropic Fluvaquents and are fertile alluvial soils (van Es et al., 1992).

The objectives of this study were 1, to determine whether regional warming is occurring in Honduras, a major tropical agricultural production zone; 2 , to determine how altitude and ambient temperature affect bean production; and 3 , to investigate how the introduction of a heat-tolerant bean variety could affect bean production, through an exante cost/benefit analysis.

\section{MATERIALS AND METHODS}

\section{Climate Analysis}

Climate change was analyzed by using data from fourteen Honduran weather stations selected on the basis of availability of reliable long-term records. The locations and number of years of weather data included Amapala, 44 yr; Catacamas, 44; Choluteca, 34; Guanaja, 43; La Ceiba, 33; La Esperanza, 8; La Mesa, 43; Nuevo Ocotepeque, 8; Puerto Lempira, 40; Roatan, 7; Santa Rosa, 44; Tegucigalpa, 46; Tela, 40 ; and Yoro, 15 . Daily maximum and minimum temperature and rainfall data from the stations were obtained from the 'Dirección General de Aeronáutica Civil de Honduras.' These data were organized for statistical analysis using Perl (open source software). Average yearly minimum and maximum temperature data were analyzed by linear regression analyses. Data from all 14 stations were included in the analysis using the SAS Proc Mixed procedure (SAS, Cary, NC, USA). The individual weather stations were considered a random variable because they were well dispersed around the country.

The GIS analysis of ambient temperatures in common bean production areas in Honduras was completed by using the most recently 
available Honduran agricultural census data (1993). The common bean production data were combined with historical average temperature data (CIAT, 1999) to yield the graphical results.

\section{Farmer Survey}

To characterize the bean farming system in Atlántida, villages were first stratified into two elevation groups: high altitude ( $\geq 250$ masl), and low altitude ( $<250$ masl). Second, five villages were selected at random to represent each elevation group. Third, the villages were visited to determine whether they fulfilled two criteria: 1) a minimum of ten bean farmers in the village; and 2) reasonable accessibility (Table 1).

Of the villages selected, only the high altitude villages were difficult to access. Farmer respondents were chosen by randomly selecting homes from the area within the perimeter of the village. The farmer was then asked whether he/she planted beans during both the 1997 Postrera (September to December) and 1998 Primera (June to August) growing seasons. Because the production analysis was based on the 1997 and 1998 growing seasons, only farmers who had planted beans during both years were interviewed. Ten interviews were conducted in each village, except for Buenos Aires, where nine were conducted, for a total sample size of 99 respondents. The interviews took place during the Primera season (May to September) of 1999.

\section{Cost Benefit Analysis}

The cost benefit analysis was carried out using data collected from the farmer survey and additional data collected from the Department of Agriculture of Honduras. Migration rates, farm level bean and corn prices, and production area data were obtained from secondary data

TABLE 1.-Villages selected for study in the Department of Atlántida, Honduras.

\begin{tabular}{llccc}
\hline Village & Municipality & $\begin{array}{c}\text { Altitude } \\
\text { (meters) }\end{array}$ & $\begin{array}{c}\text { Altitude } \\
\text { grouping }\end{array}$ & $\begin{array}{c}\text { Distance from } \\
\text { main road (hours) }\end{array}$ \\
\hline Buenos Aires & San Juan Pueblo & 400 & high & 3.5 \\
California & Jutiapa & 80 & low & 0.5 \\
Diamante & San Juan Pueblo & 130 & low & 0.4 \\
Piedras de Afilar & San Juan Pueblo & 100 & low & 0.1 \\
El Pital & La Ceiba & 250 & high & 1.0 \\
San Francisco de Saco & Arizona & 40 & low & 0.1 \\
San Marcos & La Masica & 200 & low & 1.5 \\
San Ramon & Jutiapa & 600 & high & 0.7 \\
El Toncontin & La Ceiba & 480 & high & 1.5 \\
Yaruca & La Ceiba & 400 & high & 1.3 \\
\hline
\end{tabular}

${ }^{1}$ Low $<250$; high $\geq 250$ masl. 
(e.g., national statistics/census data). Other data, such as expansion of bean production area and adoption rates were estimated from data collected through the farmer survey. On the assumption that a heattolerant variety would be released in 2010 , the estimated cost of six years of plant breeding research was factored into the six years preceding 2010. Estimates for the projected annual adoption rates for the 10year period following release are based on logistic adoption curves. The final estimates of the value of incremental production due to increased bean production were discounted for different scenarios which reflect reductions in corn production (i.e., to plant more area in beans, farmers would have to reduce their corn area). The ex ante cost benefit analysis was analyzed in Excel (Microsoft, Redmond, WA). ${ }^{7}$

We made several assumptions to estimate bean production over the 10 -year period. Increasing climatic temperatures are expected to decrease yields over the long term, 50 to 100 years. However, because of minimal effects of warming over the 10-year projection period for this study (about $0.2^{\circ} \mathrm{C}$ ), this effect was not included in the cost/benefit analysis. It was assumed that adoption rates would be similar to those of recently released varieties; thus a $33 \%$ maximum adoption rate was used. Finally, based on information from a co-author, Dr. Juan Carlos Rosas ('Escuela Agrícola Panamericana'), we assumed that yield would increase more in Primera (20\%) than in Postrera (10\%), because of the greater yield advantage of the new variety during the warmer Primera season.

\section{RESULTS}

\section{Climate Analysis}

The Honduran climate change analysis was completed by using average yearly data from the Honduran weather stations. The combined regression analysis of the 14 weather stations revealed a significant positive slope of $0.022^{\circ} \mathrm{C} /$ year for minimum temperature and $0.018^{\circ} \mathrm{C} /$ year for maximum temperature (Table 2 ). Average yearly rainfall was also analyzed. Although a negative slope was found, changes in precipitation were not statistically significant.

The GIS ambient temperature analysis based on the most recently available Honduran agricultural census data (1993) indicated that in the Primera (Figure 1) 30,669 ha $(31 \%)$ of beans were planted under high temperature stress (average maximum temperature of $>30^{\circ} \mathrm{C}$ ) and 39,009 ha $(40 \%)$ were planted in areas with moderate temperature stress

\footnotetext{
${ }^{7}$ Mention of trade names or commercial products in this article is solely for the purpose of providing specific information and does not imply recommendation or endorsement by the U.S. Department of Agriculture.
} 
TABLE 2.-Analysis of temperature change in Honduras using minimum and maximum temperature data ${ }^{1}$ from 14 weather stations ${ }^{2}$.

\begin{tabular}{lccc}
\hline Variable & $\begin{array}{c}{ }^{\circ} \mathrm{C} / \text { year } \\
\text { historic change }\end{array}$ & $\begin{array}{c}\mathrm{p} \\
\text { value }\end{array}$ & $\begin{array}{c}10 \text {-year } \\
\text { projected change }\end{array}$ \\
\hline Minimum temperature & +0.022 & $<0.0001$ & $+0.22^{\circ} \mathrm{C}$ \\
Maximum temperature & +0.018 & $<0.0001$ & $+0.18^{\circ} \mathrm{C}$ \\
\hline
\end{tabular}

'Data from the 'Direción General de Aeronáutica Civil de Honduras', Toncontin Airport, Tegucigalpa, Honduras.

${ }^{2}$ Location used as a random variable in the SAS Proc Mixed procedure (SAS, Cary, NC).

(average maximum of 28 to $30^{\circ} \mathrm{C}$ ). In the Postrera (Figure 2) 10,004 ha $(10 \%)$ were planted in areas with moderate temperature stress.

\section{Farmer Survey}

Significant differences between farmers' planted area, production, and yield in the high versus low altitude villages were found for the Primera 1997 and Postrera 1998 growing seasons (Table 3). During the Primera and Postrera seasons, the higher altitude farmers produced significantly more beans on a significantly larger land area than the lower altitude farmers. However, these total production results differed from the yield per land area results. In the 1997 and 1998 Primera growing seasons, the high altitude farmers had a $14 \%$ and $3 \%$ yield advantage, respectively, over that of the lower altitude farmers. On the
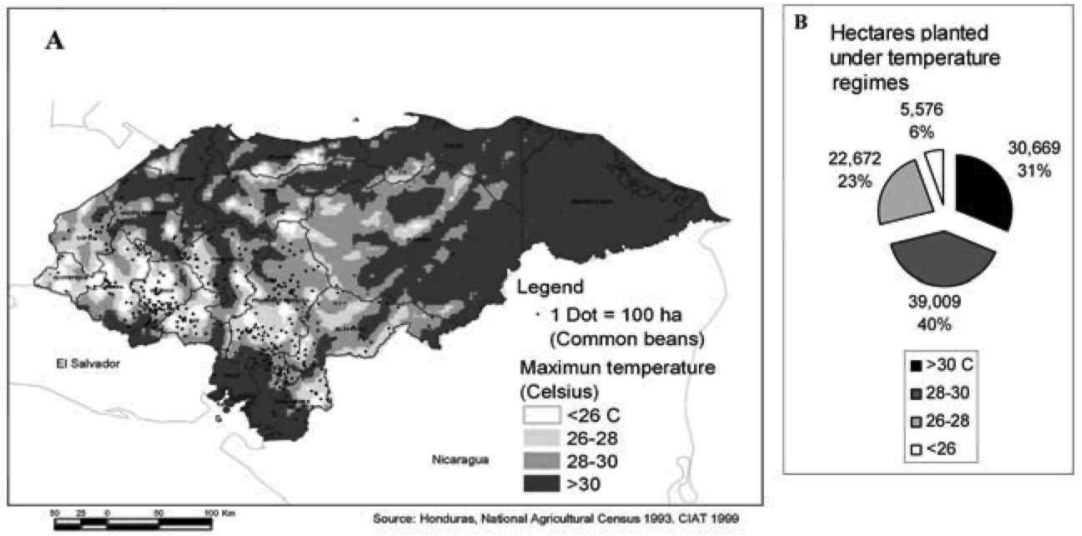

FIGURE 1. Average maximum daily temperature $\left({ }^{\circ} \mathrm{C}\right)$ during the Primera season (May to August) in Honduras. A, GIS map of Honduras showing average maximum temperature and hectares planted to common bean; $\mathrm{B}$, Hectares and percentage of bean area planted under each temperature regime. 

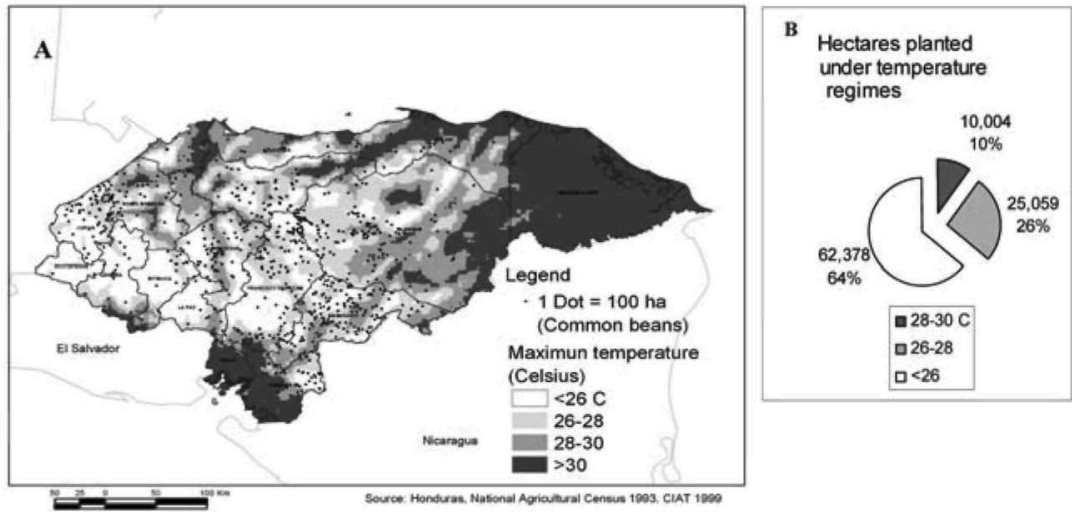

FIGURE 2. Average maximum daily temperature $\left({ }^{\circ} \mathrm{C}\right)$ during the Postrera season (September to December) in Honduras. A, GIS map of Honduras showing average maximum temperature and hectares planted to common bean; $\mathrm{B}$, Hectares and percentage of bean area planted under each temperature regime.

other hand, the lower altitude farmers showed a $64 \%$ and $19 \%$ yield advantage over that of the higher altitude farmers during the 1997 and 1998 Postrera seasons, respectively. Thus, during the higher temperature Primera season, farmers' yields were higher in the higher elevation villages; whereas in the cooler wetter Postrera season, farmers' yields were higher in the lower elevation villages.

Atlántida farmers employ a shuttle cropping system; specifically, farmers modulate the growing climate through changing the altitude of

TABLE 3.-Bean area, production, and yield in high vs. low altitude villages ${ }^{1}$.

\begin{tabular}{lccccc}
\hline Factor & Village altitude $^{2}$ & Prim. 97 & Post. 97 & Prim. 98 & Post. 98 \\
\hline Area (ha) & low & 0.25 & 0.19 & 0.29 & 0.20 \\
Area (ha) & high & 0.59 & 0.45 & 0.90 & 0.55 \\
Significance & & $*$ & $*$ & $*$ & $* *$ \\
Production (kg) & low & 258 & 361 & 294 & 138 \\
Production (kg) & high & 896 & 440 & 905 & 288 \\
Significance & & $*$ & & $*$ & $*$ \\
Yield/farmer & & & & & \\
Yield (kg/ha) & low & 689 & 967 & 817 & 531 \\
Yield (kg/ha) & high & 785 & 588 & 842 & 445 \\
Significance & & & $*$ & & \\
\hline
\end{tabular}

${ }^{1}$ Production data based on data provided by farmers during interviews.

${ }^{2}$ Low $<250$; high $\geq 250$ masl.

${ }^{3} \mathrm{Used}_{\text {sed }}$ dividual farmer yields as test statistic in the ANOVA. 
their plantings during different seasons. Whereas both high and low altitude farmers traveled into the mountains to plant during the Primera season, both groups traveled shorter distances during the Postrera. On average, farmers living in both the low and high elevation villages spent 0.44 hours commuting during the Postrera, whereas they traveled 1.14 hours to reach their higher altitude plots during the Primera. Thus both groups planted in cooler environments during the Primera season. Although both groups of farmers planted at higher altitudes during the Primera and at lower altitudes during the Postrera, farmers in the high altitude villages planted at higher altitudes during both seasons. Thus the higher altitude villages' bean fields experienced comparatively cooler growing temperatures during the Primera season and cooler temperatures and higher rainfall during the Postrera season.

The farmer survey indicated that farmers perceived high temperatures to be a constraint to higher bean yields, particularly during the Primera season. In addition, farmers reported other environmental stress factors as important production constraints, including excessive precipitation, drought, and wind (Table 4). For the Primera season, $67 \%$ of the farmers identified high temperature as the most limiting factor, whereas during the cooler and wetter Postrera season farmers reported excessive water $(65 \%)$ as their most significant constraint. Farmers in several lowland villages markedly decreased or eliminated bean production in the Primera, even though they continued to plant in the same fields during the Postrera season. During the past 15 years, California farmers have abandoned planting beans in their low elevation (50 to 150 masl) fields during the Primera because of low pod set. Few were willing to hike to the cooler, higher elevation plots located four hours away by foot. In addition, Diamante, Piedras de Afilar, and San Francisco de Saco farmers all reported reducing their Primera plantings. Thus, differences in temperature at different elevations appeared to play a role in recent changes in farmers' production practices.

TABLE 4.-Percentage of farmers perceiving climatological factors as constraints to bean production.

\begin{tabular}{lcccrc}
\hline Season & \multicolumn{2}{c}{ Primera } & & \multicolumn{2}{c}{ Postrera } \\
\cline { 1 - 3 } \cline { 5 - 6 } Village Altitude & Low & High & & Low & High \\
\hline Drought & 17 & 28 & & 2 & 7 \\
Excess Water & 23 & 18 & & 31 & 34 \\
High Temperature & 30 & 37 & & 3 & 6 \\
Wind & 21 & 23 & & 6 & 17 \\
\hline
\end{tabular}

${ }^{1}$ Low $<250$; high $\geq 250$ masl. 
Other biotic, agronomic, demographic, and social factors were also investigated to determine whether these variables could explain the differences in yield and production between the two groups of villages. Farmers were interviewed regarding their production practices, crop disease, insect pests, land degradation, land tenure and ownership, family demographics, and education. Although no significant differences between high and low altitude villages were found for most of these factors, there was a significant difference in the level of education of children who worked on the farm. On average, children in the high altitude villages had completed 3.4 years of school versus 4.8 years in low altitude villages. There were also some differences in land tenure, with higher altitude farmers owning more land in a larger number of parcels than lower altitude farmers. In addition, Hurricane Mitch passed through Honduras during the Postrera 1998 season and caused significant damage to the region and to some of the farmers' Postrera crops.

\section{Cost Benefit Analysis}

Because plant breeding involves a considerable investment of resources, a cost/benefit analysis was conducted to determine the potential return on the development of a heat-tolerant bean variety. Potential research costs for the development of a heat-tolerant variety were estimated. Farmers were surveyed to project changes in their bean production practices given the introduction of a heat-tolerant variety, and the potential economic impact of introducing a heat-tolerant variety in a high temperature growing region of Honduras, Atlántida was estimated.

In Honduras, bean breeding and crop improvement research is conducted by the Bean Breeding Program at the 'Escuela Agrícola Panamericana' (Zamorano), with financial support from international institutions, including the Bean/Cowpea CRSP and CIAT. Dr. Juan Carlos Rosas, the common bean breeder at Zamorano, estimated that it takes six years and costs roughly $\$ 60,000$ USD to develop a new common bean variety in Honduras. Furthermore, Dr. Rosas estimated that this investment in breeding for heat tolerance would increase bean yield by approximately $260 \mathrm{~kg}$ per hectare in areas subjected to high temperature stress, i.e., seasonal temperatures averaging above $30^{\circ} \mathrm{C}$ during the day or $20^{\circ} \mathrm{C}$ at night.

Surveyed farmers were asked whether, and if so, how they would change their production system if a new bean variety yielded $260 \mathrm{~kg}$ per hectare more than their current variety (Table 5). The farmers reported that they would increase their bean production area during the Primera season by $68 \%$ on average. Farmers in lower elevation villages 
TABLE 5.-Bean production factors used in the cost benefit analysis based on a 10-year projection, 2011-2020, of bean production in high temperature zones of Atlántida, Honduras.

\begin{tabular}{|c|c|c|}
\hline Factor & Primera & Postrera \\
\hline \multicolumn{3}{|l|}{ Increases in Production Area ${ }^{T}$} \\
\hline $\begin{array}{l}\text { Production area increase given the introduction } \\
\text { of new variety }\end{array}$ & $22.6 \%$ & $20.0 \%$ \\
\hline $\begin{array}{l}\text { Population growth resulting in a } 25.8 \% \text { increase } \\
\text { in production area }\end{array}$ & $2.6 \% /$ year & $2.6 \% /$ year \\
\hline Total increase due to increase in area & $48.4 \%$ & $45.8 \%$ \\
\hline \multicolumn{3}{|l|}{ Increases in Bean Yields } \\
\hline Realized potential yield due to new variety & $20.0 \%$ & $10.0 \%$ \\
\hline
\end{tabular}

${ }^{1}$ Based on assumption that one-third of the farmers would adopt the new variety.

${ }^{2}$ Benefits are generated from three sources: 1) adoption incremental production = (adopted area $x$ incremental yield), where incremental yield is the improvement in yield with the modern variety relative to the traditional variety; 2 ) expansion area $=$ (adopted area $\times \%$ of farmers expanding area $\times$ expansion amount); i.e., a farmer has to first adopt the new variety before he/she can expand area attributed to that new variety; and 3) migrant area expansion $=($ migration rate $\times$ current bean area $)$; migrant adopted area $=($ migrant area expansion $\times$ adoption rate); migrant incremental production $=($ migrant adopted area $x$ incremental yield).

projected that they would increase their bean growing area by $81 \%$ versus $61 \%$ in high altitude villages. In addition, few farmers (less than $5 \%$ ) said that they would acquire new properties for planting the improved bean variety. In order to determine access, acceptance, and use of improved varieties, farmers were asked about their use of common bean germplasm. Almost all of the surveyed farmers in Atlántida grew beans of the small red market class; however, approximately $7 \%$ also planted black beans. Approximately $48 \%$ of the farmers had heard of one or more of the improved varieties that had been released by the Zamorano Bean Program, and 34\% had tested one of the improved varieties through association with a non-governmental organization (NGO) or on their own (Table 6). Of the improved varieties that have been released by Zamorano, farmers regularly planted only two. Farmers in four out of the 10 villages had no knowledge of any of the improved varieties, and $67 \%$ of the farmers planted only landraces.

Given the assumptions of population growth, yield increases, production area increases, and adoption rates, we estimated the potential increase in bean yield due to the introduction of a heat-tolerant variety in Atlántida. The adoption pattern was estimated with a logistic regression in order to account for a non-linear adoption of the new variety in the 10-year period. The opportunity cost estimates are based on the assumption that the farmers who increased their bean area would likely 
TABLE 6.-Landrace and improved variety usage by farmers in 1999.

\begin{tabular}{llcccc}
\hline Variety name & $\begin{array}{c}\text { Seed type } \\
\text { (all small } \\
\text { seeded) }\end{array}$ & $\begin{array}{c}\text { Genotype } \\
\text { origin }^{1}\end{array}$ & $\begin{array}{c}\text { Current use } \\
\text { (\% of farmers) }\end{array}$ & $\begin{array}{c}\text { Distribution } \\
\text { (No. villages) }\end{array}$ & $\begin{array}{c}\text { Average use } \\
\text { (years) }\end{array}$ \\
\hline Arbolito Retinto & Dark red & LR & 69 & 10 & 12.4 \\
Arbolito Rojo & Bright red & LR & 17 & 3 & 11.0 \\
Cincuenteño & Bright red & LR & 58 & 8 & 12.1 \\
Dorado & Dark red & MV & 8 & 3 & 1.5 \\
Martínez & Bright red & LR & 7 & 1 & 9.9 \\
Negro & Black & LR & 7 & 4 & 15.0 \\
Payulo & Bright red & LR & 9 & 1 & 11.4 \\
Tío Canela 75 & Dark red & MV & 18 & 5 & 1.6 \\
Zamorano & Dark red & LR & 7 & 2 & 4.0 \\
\hline
\end{tabular}

${ }^{1}$ LR-Landrace; MV-Modern Variety

reduce the time and resources devoted to other agricultural enterprises. As most bean farmers also grow maize, it was assumed that the reduction would come in maize production. The opportunity cost scenarios used net returns per hectare of maize as the opportunity cost, with various assumptions regarding the proportion of maize area reduction for every additional hectare of common bean (i.e., 1.0 ha allocated to beans results in a $1.0,0.5$ or a 0.25 ha reduction in the maize area). With the introduction of a heat-tolerant variety in $2010,3,244$ to 3,338 additional metric tons of beans could be produced between 2011 and 2020 in Atlántida, with an estimated net present value between $\$ 388,000$ and $\$ 720,000$ USD, depending on the opportunity cost assumption (Table 7). The rate of return for the investment in a heat-tolerant variety in Atlántida, discounting plant breeding costs, is therefore between 28 and $38 \%$.

\section{DISCUSSION AND CONCLUSIONS}

This study has found that climatic warming is occurring in Honduras. Bean farmers in the high temperature lowlands of Atlántida avoid heat stress by planting at higher elevations. Farmers are also interested in increasing their bean production by planting heat-tolerant varieties. Although the benefits of the introduction of a higher yielding, heat-tolerant variety outweigh the costs, challenges do exist for increasing the production of common bean in the lowland tropics.

This study found that average minimum temperature has risen in Honduras by $0.022^{\circ} \mathrm{C} / \mathrm{yr}$ and maximum temperature by $0.018^{\circ} \mathrm{C} / \mathrm{yr}$. These values closely reflect world-wide global warming rates. Although few similar studies have been conducted in tropical areas, this study indicates that regional warming is occurring and that minimum 
TABLE 7.-Net present value in USD of projected additional bean production, during the years 2011 to 2020, due to the introduction of a heat-tolerant variety in Postrera and Primera in Atlantida, Honduras, given a range of opportunity costs to maize production. Projected scenarios based on responses from farmers in high ( $\geq 250$ masl) and low (<250 masl) altitude villages in Atlántida.

\begin{tabular}{lccccc}
\hline Scenario & $\begin{array}{c}\text { Incremental } \\
\text { production } \\
\text { (metric tons) }\end{array}$ & $\begin{array}{c}\text { Net present } \\
\text { value } \\
\text { OC }=0^{2}\end{array}$ & $\begin{array}{c}\text { Net present } \\
\text { value } \\
\text { OC }=1 / 4\end{array}$ & $\begin{array}{c}\text { Net present } \\
\text { value } \\
\text { OC }=1 / 2\end{array}$ & $\begin{array}{c}\text { Net present } \\
\text { value } \\
\text { OC }=1 / 1\end{array}$ \\
\hline $\begin{array}{l}\text { High Altitude } \\
\text { Rate of Return }\end{array}$ & 3,244 & $\$ 697,561$ & $\$ 627,162$ & $\$ 556,762$ & $\$ 415,962$ \\
Low Altitude & 3,338 & $\$ 719,575$ & $\$ 636,636$ & $\$ 553,698$ & $\$ 387,821$ \\
Rate of Return & & $38 \%$ & $36 \%$ & $34 \%$ & $28 \%$ \\
\hline
\end{tabular}

${ }^{1}$ Estimates calculated from historic maize yield averages and farm level prices.

${ }^{2}$ Opportunity costs $(\mathrm{OC})$ of increased bean production on maize production. Ratio indicates proportion of maize area reduced for every hectare of bean area increase.

temperatures in Honduras are rising more rapidly than maximum temperatures. This asymmetric day/night warming trend in temperature will have a greater impact on crops sensitive to high night temperatures, such as common bean. In addition, GIS analysis found approximately $31 \%$ of Primera bean production in Honduras to be under high temperature stress $\left(>30^{\circ} \mathrm{C}\right)$.

In Atlántida, Honduran farmers plant at higher elevations during the Primera season and at lower elevations during the Postrera seasons to maximize bean yields. Production and yield patterns were found to be dependent on the elevation of the field sites. Thus farmers traveled to higher elevations to plant during the higher temperature season to avoid heat stress. Other researchers (Humphries, personal communication) have also observed seasonal variation in planting locations and commuting distances on the north coast of Honduras. Similarly, Jansen (1998) observed seasonally dependent locations for bean and maize planting, all of which he attributed to the soil's waterholding capacity, fertility and soil type in El Zapote, Honduras. Although higher altitude planting alleviates heat stress, physical distance and traveling time negatively affect productivity.

Factors in addition to village elevation may also affect production and yield patterns between the two groups of villages. Land degradation, insect pests, diseases, production system, profitability of production, varietal usage, and family size were similar between the two groups of villages. However, child education and land tenure patterns differed between high and low altitude villages. Higher altitude farmers owned more land and had a larger number of parcels, thus possibly allowing these farmers to utilize longer fallow periods. 
The cost/benefit analysis indicated that investing in research to develop heat-tolerant varieties for the high temperature zone of Atlántida is a sound economic investment. Farmer adoption of heat-tolerant varieties will generate an estimated return of between $\$ 388,000$ and $\$ 720,000$ USD over a 10 -year period, whereas the cost of developing a new variety is estimated to be $\$ 60,000 \mathrm{USD}$. Thus the rate of return on this investment is between 28 and $38 \%$. When considering that the same varieties developed in Honduras are also widely planted in other countries of Central America, the value of this research investment becomes more apparent and the difference between the costs and benefits becomes more dramatic.

The greater willingness of farmers at low altitudes to increase their bean production area indicates a potential to shift bean production from the fragile higher altitude areas to lower zones during the Primera season. Increasing the bean production area does not necessarily require farmers to acquire new land because farmers in this region "own" relatively large parcels of land, most of which are fallow. However, the intensification of production could result in increased land degradation, shorter fallow periods, and thus the invasion of additional forest reserves. Heat-tolerant varieties may make bean production at lower altitudes feasible. Reduced incidence of some plant pathogens, flatter land, better soil fertility, and increased access to markets are additional advantages of lowland production. However, competition with ranchers over pasture land, higher land prices (Humphries, 1998), weed and pest problems, and disease pressure (web blight and BGMV) are constraints to increasing bean production in the lowlands.

Increasing lowland bean production will require the development of germplasm with disease resistance in addition to heat tolerance. However, it becomes increasingly difficult, expensive, and time consuming to combine large numbers of traits into a single variety. Another solution would be the release of season-specific varieties. Among the farmers interviewed on the North coast, $80 \%$ planted multiple cultivars or landraces each season to compensate for disease and abiotic constraints, to stagger maturity for food security, to produce beans for different markets, or for experimentation. Thus a framework already exists for introducing different varieties specific to the Primera and Postrera seasons. These improved varieties would not only be beneficial to Honduran bean production, but also to that of other comparable climatological zones because the Mesoamerican race of Phaseolus vulgaris, which includes red beans, is planted over the largest area worldwide. The recent release of the heat-tolerant variety Amadeus 77 in 2004 (Rosas et al., 2004) and its rapid adoption by farmers in Atlántida suggests that breeding for heat tolerance in conjunction with 
disease resistance is a viable approach to increasing production of common bean in the high temperature lowland tropics.

Considering the sensitivity of bean to high temperature stress and the climatic warming trend in Honduras, future bean production in the high temperature regions (i.e., low altitude) of Honduras is in peril. Global studies on climate change indicate that climatic warming will continue for the foreseeable future; thus future production in Honduras and in other high temperature zones worldwide will depend on altering the response of bean to the environment. Through the genetic improvement of heat tolerance in common bean, a cost effective strategy, yields could remain stable or potentially increase.

\section{LITERATURE CITED}

Alward, R. D., J. K. Detling and D. G. Milchunas, 1999. Grassland vegetation changes and nocturnal global warming. Science 283:5399.

Centro Internacional de Agricultura Tropical-CIAT, 1999. Lluvia anual, temperatura mínima, temperatura máxima, elevación $(5 \mathrm{~km})$ de Honduras, Edition V.1. CIAT, Cali, Colombia.

Easterling, D. R., B. Horton, P. D. Jones, T. C. Peterson, T. R. Karl, D. E. Parker, M. J. Salinger, V. Razuvayev, N. Plummer, P. Jamason and C. K. Folland, 1997. Maximum and minimum temperature trends for the globe. Science 277:364-367.

Easterling, D. R., G. A. Meehl, C. Parmesan, S. A. Changnon, T. R. Karl and L. O. Mearns, 2000. Climate extremes: observations, modeling, and impacts. Science 289:2068-2074.

Gross, Y. and J. Kigel, 1994. Differential sensitivity to high temperature of stages in the reproductive development of common bean Phaseolus vulgaris L. Field Crop Res. $36: 201-212$.

Harvey, D. L., 1995. Warm days, hot nights. Nature 377: 15-16.

Humphries, S., 1996. Migrants, dairy farmers and agricultural land-use in the humid, tropical hillsides of Northern Honduras. Department of Sociology and Anthropology, University of Guelph, Ontario.

Humphries, S., 1998. Milk cows, migrants, and land markets: unraveling the complexities of forest-to-pasture conversion in Northern Honduras. Econ. Devel. Cult. Change 47:95-124.

Jansen, K, 1998. Political Ecology, Mountain Agriculture and Knowledge in Honduras. Thela Publishers, Amsterdam.

Konsens, I., M. Ofir and J. Kigel, 1991. The effect of temperature on the production and abscission of flowers and pods in snap bean Phaseolus vulgaris L. Ann. Bot. 67:391-400.

Porch, T. G. and M. Jahn, 2001. Effects of high temperature stress on microsporogenesis in heat-sensitive and heat-tolerant genotypes of Phaseolus vulgaris. Plant Cell Environ. 24:723-731.

Portillo, N. P., 1997. Geografía de Honduras. 3rd Edition. Tegucigalpa, Honduras.

Rainey, K. M. and P. D. Griffiths, 2002. Evaluation of snap bean breeding lines for heat tolerance. HortScience 37:444.

Román-Avilés, B. and J. Beaver, 2003. Inheritance of heat tolerance in common bean of Andean origin. e. Agric. Univ. P.R. 87:113-121.

Román-Avilés, B. and J. Beaver, 2001. Heritability of heat tolerance of an Andean bean population. Annu. Rep. Bean. Improv. Coop. 44:49-50. 
Rosas, J. C., A. Castro, J. Beaver, C. A. Pérez, A. Morales and R. Lepiz, 1999. Mejoramiento genético para tolerancia a altas temperaturas y resistencia a mosaico dorado en frijol común. Agronomía Mesoamericana 11:1-10.

Rosas, J. C., J. S. Beaver, M. Alameda-Lozada, D. Escoto, J.C. Hernández and R. Araya, 2004. Registration of 'Amadeus 77' small red common bean. Crop Sci. 44:18671868.

Rosenzweig, C. and D. Hillel, 1998. Climate Change and the Global Harvest: Potential Impacts of the Greenhouse Effect on Agriculture. Oxford University Press, New York.

Simmons, C. S., 1969. Informe al gobierno de Honduras sobre los suelos de Honduras. FAO, Rome.

Stott, P. A., S. F. B. Tett, G. S. Jones, M. R. Allen, J. F. B. Mitchell and G. J. Jenkins, 2000. External control of 20th century temperature by natural and anthropogenic foreings. Science 290:2133-2137.

Sunderlin, W. D., 1998. Deforestation, livelihoods, and the preconditions for sustainable management in Olancho, Honduras. Agr. Human Values 14:373-387.

Triomphe, B. L., 1996. Seasonal nitrogen dynamics and long-term change properties under the Mucuna/maize cropping system on the hillsides of Northern Honduras. (Thesis) Cornell University, Ithaca, New York.

UPEG, 1998a. Compendio Estadístico Agropecuario 1997. Tegucigalpa, Honduras: Secretaría de Agricultura y Ganadería. pp. 3-6.

UPEG, 1998b. Compendio Estadístico Agropecuario 1997. Tegucigalpa, Honduras: Secretaría de Agricultura y Ganadería. pp. 2, 9.

van Es, H., R. B. Bryant, S. W. Waltman and M. Okulcz-Kozaryn, 1992. General Soils Map and Interpretative Maps of Honduras. USDA-Soil Conservation Service, Cornell University, Ithaca, New York.

van Wambeke, A., 1992. Soils of the Tropics. McGraw Hill, New York.

Warrag, M. O. A. and A. E. Hall, 1984. Reproductive responses of cowpea Vigna unguiculata L. Walp. to heat stress. II. Responses to night air temperature. Field Crop Res. 8:17-33.

Went, F. W., 1945. Plant growth under controlled conditions. V. The relation between age, light, variety and thermoperiodicity of tomatoes. Am. J. Bot. 32:469-479.

Zavala, P. A., 1993. Econometric models of supply and demand for beans and corn in Honduras. (Thesis) Cornell University, Ithaca, New York.

Zuniga, A. E., 1990. Las modalidades de la lluvia en Honduras. Editorial Guaymuras, Tegucigalpa, Honduras. 